Research Article

\title{
First record of the genus Metacirolana sp. and Cymodoce tribullis (Crustacea; Isopoda) from South Andaman, Andaman Islands, India
}

\author{
Anil Pathan*, Ameen Ummath, Bijin Mohammad PS, Kaderambil Arjunan Jayaraj \\ Department of Ocean studies and Marine Biology, School of Life Sciences Pondicherry University, Port Blair \\ Campus, Andaman Islands 744112, India
}

\author{
Article history: \\ Submission April 2019 \\ Revised December 2019 \\ Accepted April 2020 \\ *Corresponding author: \\ E-mail: \\ anil.federer070@gmail.com
}

\begin{abstract}
Isopoda are one of the most poorly known crustaceans in Andaman and Nicobar Islands. The present study has recorded genus Metacirolana sp. and Cymodoce tribullis, for the first time from South Andaman. This recent sighting provides a new distribution of this two species in the Indian province. The specimens were collected from the seaweeds of intertidal regions of Kodiyaghat, South Andaman, Andaman Islands. The morphological characteristics of these two species were described. Furthermore, this study adds two more species to the isopoda check list of Andaman and Nicobar Islands. The present study also provides additional information on epifaunal communities associated with the seaweeds in the intertidal region of Kodiyaghat, South Andaman.
\end{abstract}

Keywords: New records, Seaweeds, Metacirolana sp., Cymodoce tribullis, South Andaman, Andaman Islands, India

\section{Introduction}

The Cirolanidae are the group of isopods distributed worldwide, ranging from marine, estuarine to some freshwater species [1]. Around the world sixty-one genera and 497 species of Cirolanidae are reported, of which 44 genera and 412 species are marine in nature [2]. Members of this family are among the most abundant and specious isopods of shallow marine environments [3] and extend from a maximum depth of approximately 3000 meters [4] but the greatest diversity are found in the tropical waters [5]. The genus Metacirolana is distributed worldwide in both temperate and tropical oceans, and extends up to 2000 meters in depth [6]. Metacirolana occurs throughout the Indian and Pacific Oceans as well as the tropical western Atlantic waters [7]. The maximum diversity of Metacirolana is found to be on coral reefs and tropical shallow-water habitats accounting about 17 species out of 34 known species. Furthermore, the taxonomists are aware of numerous undescribed species in the coral reefs of Pacific, In- dian Oceans and Northern Pacific [8]. In the family Sphaeromatidae, Cymodoce Leach, 1814 was one of the first sphaeromatid genera to be described and it is considered to be the largest genus with about 70 species [9]. They are predominantly found on the continental shelf with four species known from depths greater than about 200 meters. They have global occurrence except in Polar waters [10]. Harrison and Holdich (1984) reviewed genus Cymodoce. Later Khalaji et al., (2013, 2014, 2016) had given a detailed account of this genus.

Algae are the primary producers of ocean and forms the base of marine food chain [14]. Varying from unicellular phytoplankton to the giant multicellular macrophytes [15, 16]. Seaweed, as benthic primary producer, plays a significant role in the food web of many coastal environments, particularly on rocky intertidal areas [17]. Seaweeds need a hard substratum for attachment, and rocky intertidal regions provide a suitable environment for their growth [18]. Seaweeds also have a major sig- 


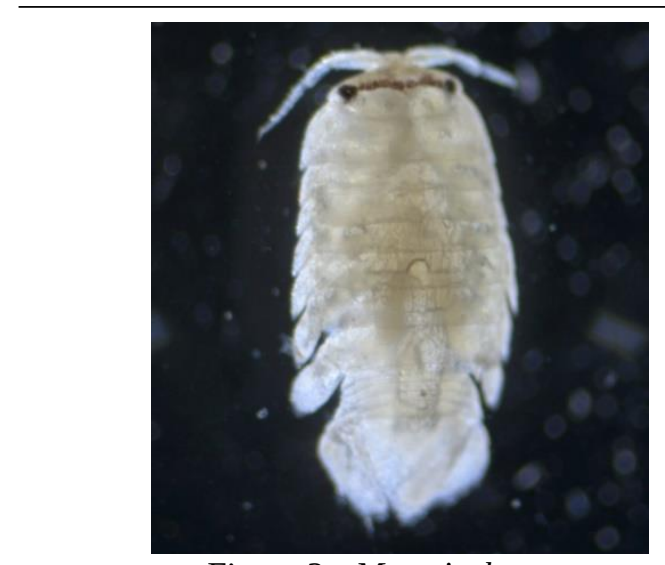

Figure 2. Metacirolana sp.
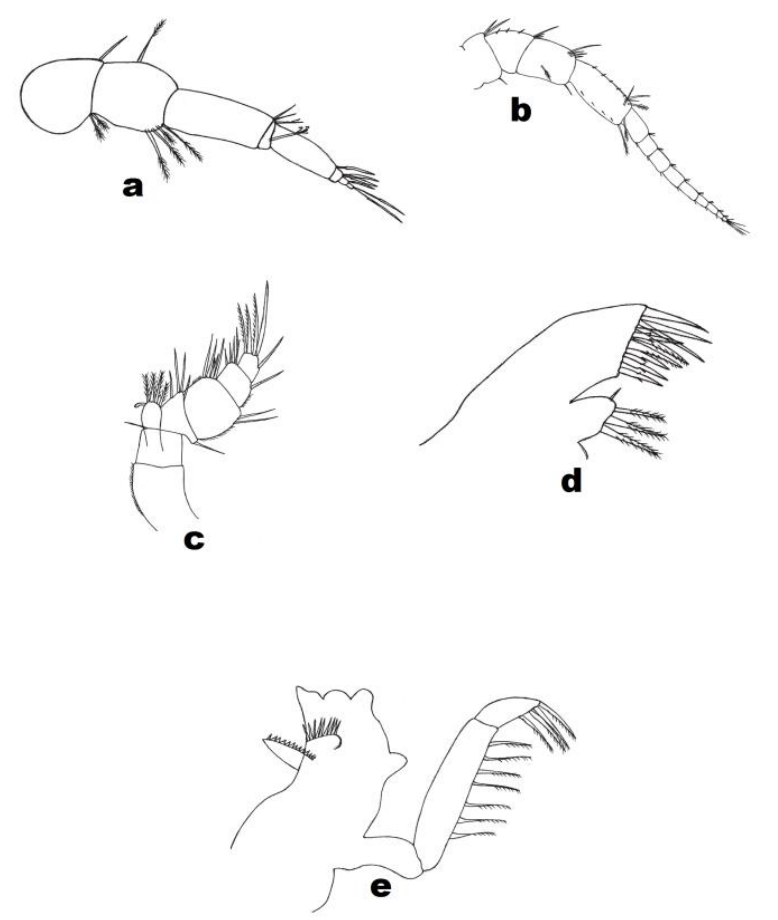

Figure 3. Metacirolana sp.: antennules (a), antenna (b), maxilliped (c), maxillia (d), and mandible (e)

were visible in dorsal view, they become progressively larger posteriorly; coxae of pereonite 7 was largest and extended well beyond pleonite 5 . Pleon with 5 distinct pleonites; lateral margines were not overlapped; dorsal surface of the pleonites was smooth (Figure 2).

Antennule was short and reaching to the posterior margin of cephalon; peduncle 3 articulate, first two articles widest and sub equal in length; 3rd article was elongated; inferior distal margins of article 1 two plumose setae and article 2 four plumose setae was present; flagellum consist of five articles, second article was longest compared to the remaining four articles (Figure 3a). Antenna reaching up to posterior margin of pereonite two; peduncle 5 articulate, peduncular articles 1 and 2 partially fused; flagellum consist of nine articles (Figure 3b).

Frontal lamina is narrow posteriorly, expanded and rounded anteriorly; anterior expansion overlaps basal articles of antennules. Maxillipedal palp articles subrectangular, margins with many long simple and comb setae; endite small, with four plumose setae and one simple seta, with one coupling hook spine (Figure 3c). Maxillules medial lobe with one small apical spine, in addition to the three circumplumose spines and two simple setae; lateral lobe with ten stout spines, many strongly barbed (see Figure 3d). Mandibular incisor tridentate; spine row with 9 long thin spines; palp three-articulate, terminal article with comb setae, middle article longest with comb setae (Figure 3e).

Pereopod 1 is short and stout; inferior margin of merus with three very short blunt squamate spines, one simple setae and two serrate spines; carpus was very short, inferior margin with one serrate spine and two simple setae; inferior margin of propodus with three basally serrate spines and simple setae; dactylus with one small simple spine at the base of unguis (Figure 4a). Pereopod 7 ambulatory with simple setae and serrate spines (Figure 4b).

Peduncle of pleopod 1 medial margin with three coupling spines, lateral margin with one seta; both rami setigerous (Figure 4c). Medial margin of pleopod 2 peduncle have three coupling spines and one plumose seta, lateral margin with one long and many short setae; both rami setigerous (Figure 4d). Peduncle of pleopods 3 and 4 medial margins with three coupling spines, lateral margins with one large spine; both ramis are setigerous (Figures 4e 4f). Peduncle of pleopod 5 lateral margin with one simple spine; endopod is non-setigerous (Figure $4 \mathrm{~g}$ ). Pleopodal exopods 3 to 5 with complete medial transverse incision is present.

Uropodal peduncle with two robust ventral setae arising from ventral side of the uropodal rami; exopod distinctly shorter than endopod and does not extend to pleotelson apex, outer medial margin with two spines interspersed with plumose setae and simple setae, inner lateral margin with two another two spines mix with two plumose setae. Endopod extends to nearly pleotelson apex; inner distal margin with one large spine spine interspersed 


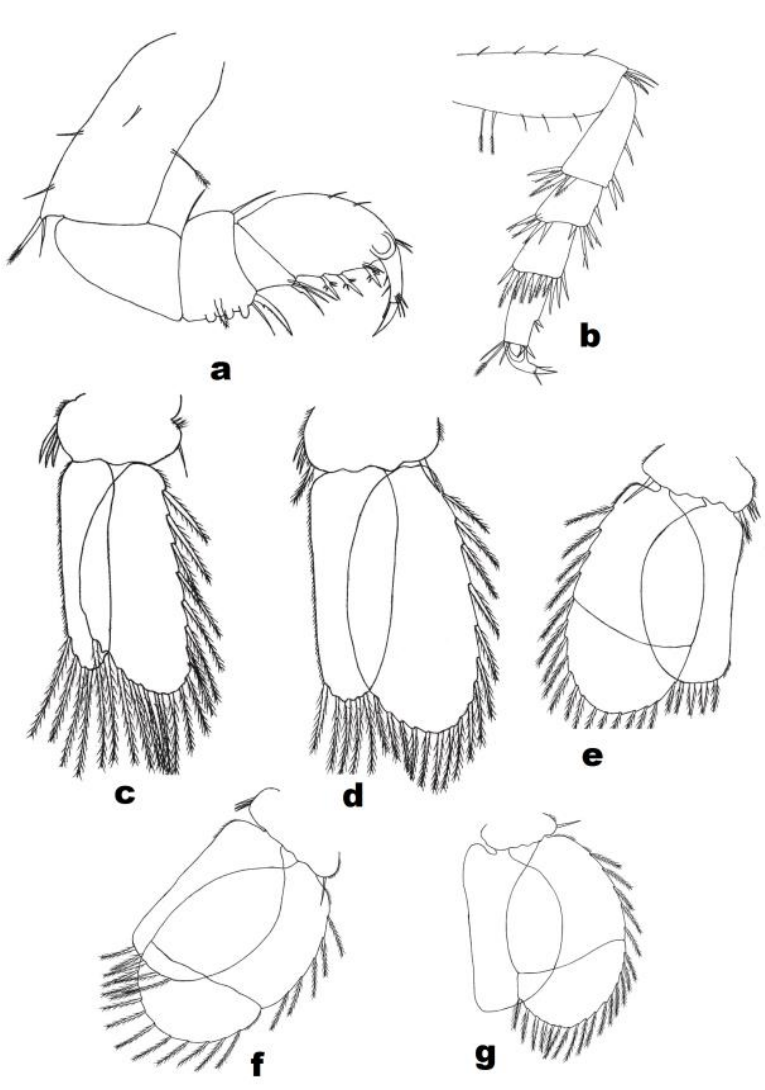

Figure 4. Metacirolana sp.: pereopod 1 (a), pereopod 7 (b), pleopod 1 (c), pleopod 2 (d), pleopod 3 (e), pleopod 4 (f), and pleopod 5 (g)
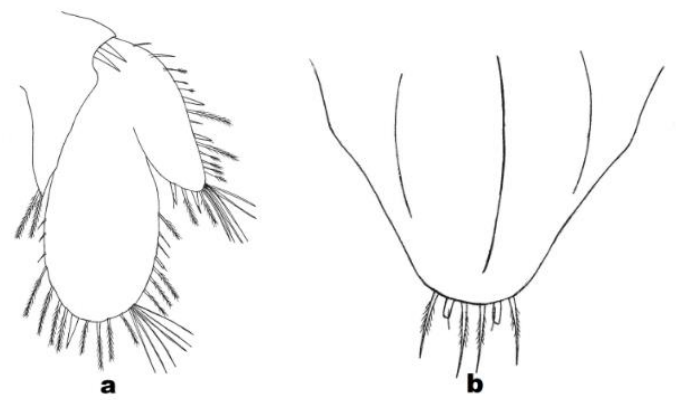

Figure 5. Metacirolana sp.: uropods (a), pleotelson (b)

with plumose marginal setae and simple setae, outer medial margin with one small spine and plumose marginal setae and simple setae (Figure 5a). Uropods with small apical notch on each ramus; six simple long setae were arising from each notch. Pleotelson subtriangular, anterior lateral margins are straight and posterior lateral margins are slightly concave, dorsal surface have a median longitudinal carina, flanked by two submedian longitudinal carinae; pleotelson posterior margin with two round marginal spines and four plumose setae (Figure 5b).

\section{Family Sphaeromatidae Latreille Genus Cymodoce Leach 1814Cymodoce tribullis Harrison and Holdich 1984 Description}

Dorsal surface of cephalosome and pereonites 1-4 posterior and lateral margins very fine granules and setae are present they are not clearly visible. Posterior margin of pereonite 5 with one row of tubercles. Posterior margin of pereonites 6, 7 each with two transverse rows of small tubercles. Posterior margin of pereonite 7 have 4 pronounced tufts of setae. Dorsal surface of pleon with many scattered uneven tubercles of various sizes; posterior margin with 4 pronounced tufts of setae; lateral regions bearing many long setae (Figure 6).

Antennule with peduncle article 1 is large and expended, it is clearly visible in dorsal view of organisam, article 2 was short; articles 1 and 2 were granulose; article 3 was narrow, cylindrical, smooth; flagellum consist of 16 articles and extending to level of pereonite 2 (Figure 7a). Antenna 2 slender, 21-articled flagellum extending to the level of pereonite 4 (Figure 7b).

Epistome with triangular acute apex, anterolateral margin straight, lateral margins concave (Figure 7c). Maxilliped endite mesial margin with 3 stout spines and single coupling hook, distal margin with 8 blunt rarely plumose setae; palp articles 2-4 lacking single simple seta on superior distal angle (Figure 7d). Maxilla 1 with inner lobe bearing 4 pectinate spines; outer lobe bearing approximately 10 moderately stout spines (Figure 7e). Mandible with incisor process and lacinia mobilis of left side bluntly dentate (Figure 7f).

Pereopods moderately slender. Pereopod 1 with ischium bearing one superior median spine; merus and carpus bearing inferior pads of short setae; merus with superior distal lobe bearing three spines, inferior margin bearing three spines; carpus with three inferior spines and superior distal lobe bearing two plumose setae; propodus with three inferior spines (Figure 8a). Perepods 2-6 each with merus, carpus and propodus bearing inferior fringes of fine setae and slender spines (Figure $8 \mathrm{~b}$ ). Pereopod 7 with ischium bearing one long superior spine; merus and carpus each with a small group of superior distal spines, and a row of long inferior spines; propodus lacking inferior setae, bearing four equidistant inferior spines (Figure $8 \mathrm{c})$.

Basis of pleopod 1 bearing four internal coupling hooks; endopod narrow, subtriangular, inner N32221 margin bearing a longitudinal fold; exo- 


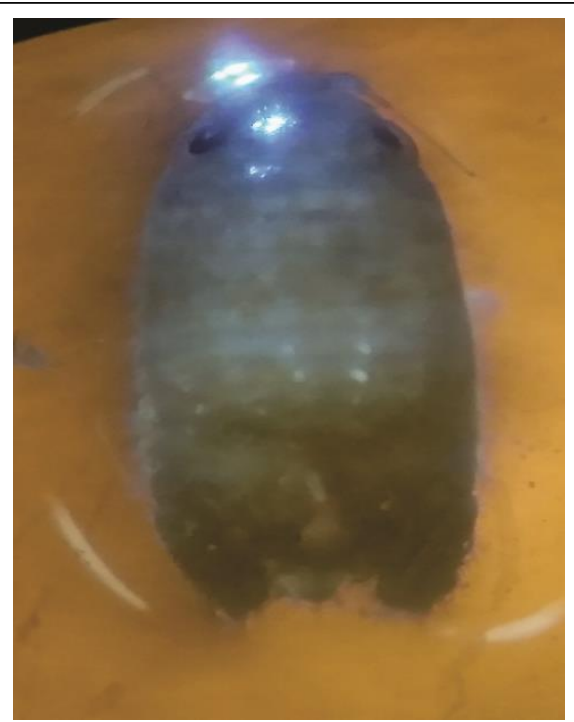

Figure 6. Cymodoce tribullis

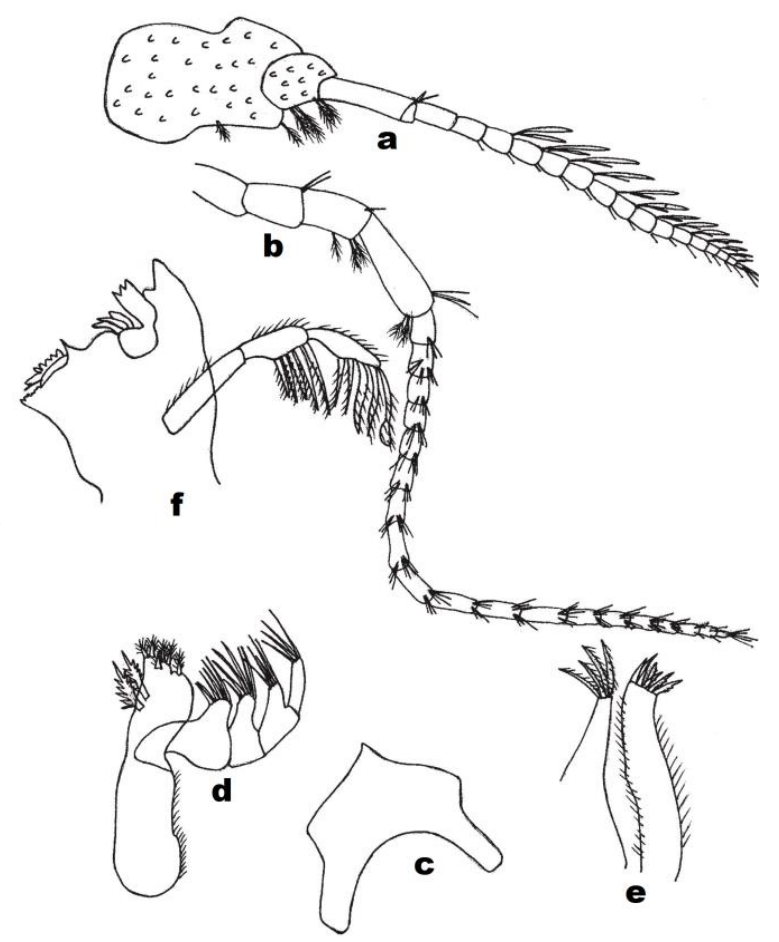

Figure 7. Cymodoce tribullis: antennules (a), antenna (b), frontal lamina (c), maxilliped (d), maxillia (e), mandible (f)

pod subelliptical, slightly longer than endopod (Figure 9a). Pleopod 2 with basis bearing four internal coupling hooks; appendix masculine arising at the internal margin of endopod. Appendix masculine slender, extending slightly beyond endopod with narrowly rounded apex; proximally covered with small hook like scales and distal part bearing short marginal setae (Figure 9b). Pleopod 3 with basis bearing two internal coupling hooks; endo- pod broad, subtriangular, apex narrowly truncate; exopod subelliptical, slightly longer than endopod with a complete subterminal articulation (Figure 9c). Endopod of pleopod 4 narrow with an internal, subterminal indentation, apex narrowly rounded with one long seta; exopod broad, subtriangular, with short, simple, external setae and a complete subterminal articulation (Figure 9d). Exopod of pleopod 5 with 4 scale patches; endopod distolateral margin fringed with fine setae (Figure 10a).

Uropodal ramus was subequal, extending just beyond pleotelsonic median apical tooth. Endopod of uropod was subrectangular, distal margin slightly oblique, externo-distal angle acute; dorsal surface granulose; lateral margins bearing long setae, ventral surface with a longitudinal row of small groups of short, stiff, dark brown setae. Exopod of uropod was lanceolate, ventrally and laterally setose; external margin was in slight sinuate form; internal margin smoothly arcuate, tapering to long acute apex (Figure10 b).

Pleotelson bearing scattered, small, prominent tubercles; anterior region with a prominent longitudinal ridge on either side of midline; dilating posteriorly as a boss bearing a blunt bifid process; ridges bearing many long setae; processes on bosses bearing long setae in the cleft, and an internal row of short, stiff, dark brown setae; region lateral to ridges with two prominent tubercles, one posterior to the other. Posterior region of pleotelson, in midline, with a large smoothly domed boss, covering by small setae. Apex of pleotelson markedly tridentate; lateral teeth blunt, uneven; median tooth extending well beyond the level of lateral teeth, broad, apically emarginate, with a ventral subterminal row of short, stiff, dark brown setae (Figure10 c).

\section{Remarks}

The present specimen is most closely resembling to the Cymodoce tribullis, the specimen described by Harrison and Holdich (1984). Dorsal surface of posterior and lateral margins of pereonites 1-4 have fine granules and setae. Pereonite 5 have one row of tubercles. Posterior margin of pereonite 7 with four pronounced tufts of setae. Maxilliped endite mesial margin with 3 stout spines and single coupling hook; palp articles 2-4 lacking simple seta on superiodistal angle. Merus of pereopod 1 with superior distal lobe bearing 


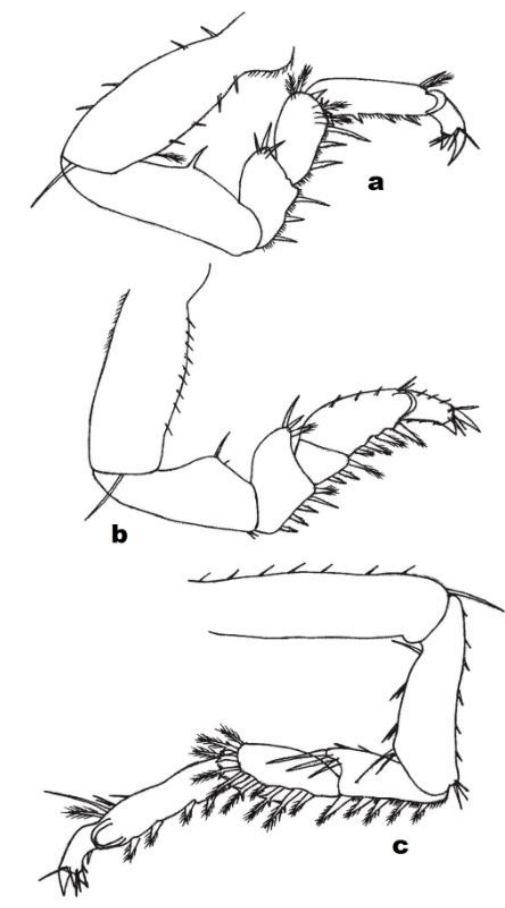

Figure 8. C. tribullis: pereopod 1 (a), pereopod 2(b), pereopod 7(c)

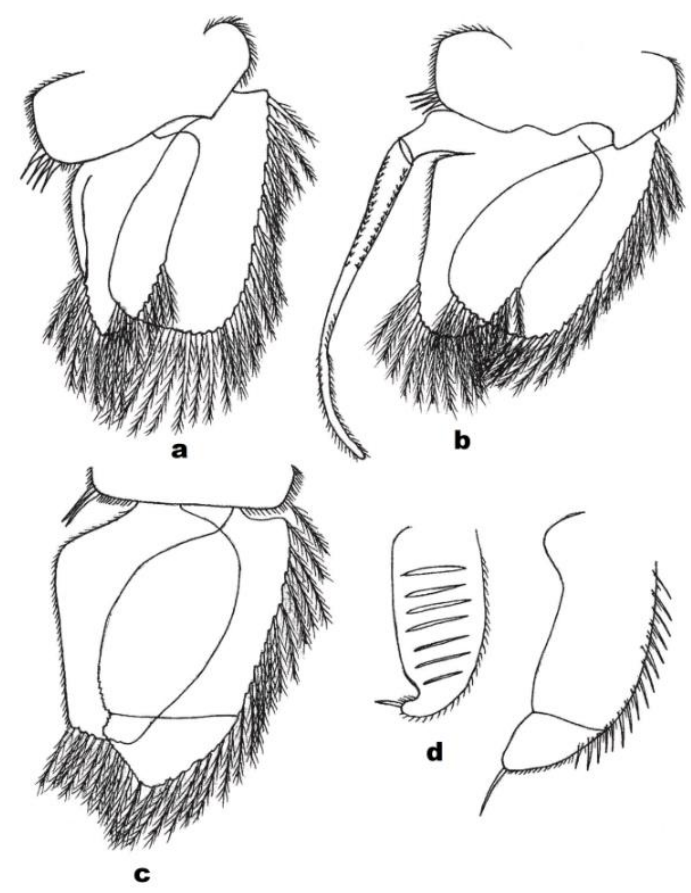

Figure 9. C. tribullis: pleopod 1 (a), pleopod 2 (b), pleopod 3 (c), pleopod 4 (d)

three spines, inferior margin bearing three spines; propodus with three inferior spines. Pleopod 2 with basis bearing four internal coupling hooks; appendix masculine proximally covered with small hook like scales. Basis of pleopod 3 with two internal coupling hooks. Exopod of pleopod 5 with 4 scale patches. External margin of exopod of uropods is present in slight sinuate form.

The specimen in this study is also similar to the Cymodoce waegelei the specimen described by Khalaji-Pirbalouty and Raupach (2014). However, specimen described in the present study was lacking scattered tubercles in the pleotelson between two large prominent bifid bosses, flanked on lateral side by 2 prominent tubercles compared to the specimen described by Khalaji-Pirbalouty (2014). Medial lobe of the pleotelson is less extended then that of Cymodoce waegelei. In Cymodoce waegelei exopod of pleopod 5 has one slender simple marginal seta present on the upper transverse suture, which is absent in the present specimen.

In Andaman and Nicober Islands, under the family Cirolinidae, 3 species were reported viz, Excirolana orientalis in Nicobar, Cirolana parva in Little Andaman and Dolicholana elongate in Andaman Islands [21]. In the family Sphaeromatidae, genus Cymodoce with one species C. longistylis was reported by Barnard (1936) from Nicobar Islands. Till now no reports were published regarding the genus Metacirolana and Cymodoce tribullis. Genus Metacirolana can be distinguished from other cirolanids by its relatively small size (mostly between 1.5 and $3.5 \mathrm{~mm}$ ), with the largest deepsea species, Metacirolana neocaledonica having $13 \mathrm{~mm}$ in length [8]. Commonly, the size of the marine isopods ranges from approximately 1 $\mathrm{mm}$ (smallest asellotes and anthuroids) and upto $350 \mathrm{~mm}$ (Bathynomus giganteus) the largest of all isopods [23]. Genus Metacirolana shows wide range of distribution particularly from the surrounding waters of Andaman and Nicobar Islands like Singapore [24] and Indonesia [8] these small organisms' range geographically extending from the Andaman and Nicobar Islands. Cymodoce tribullis was first reported by Harrison and Holdich (1984) from dead intertidal coral and floating algae at Magnetic Island, Townsville in Australia. Sidabalok (2013) reported these species from Sumatera Island (Indonesia) and recently Bruce and Wong (2015) reported these species from Singapore waters. Cymodoce tribullis mostly distributed in the waters of Southern Vietnam, northeastern Australia.

Seaweeds like marine macro-algae in the marine intertidal zone provides a suitable environ- 


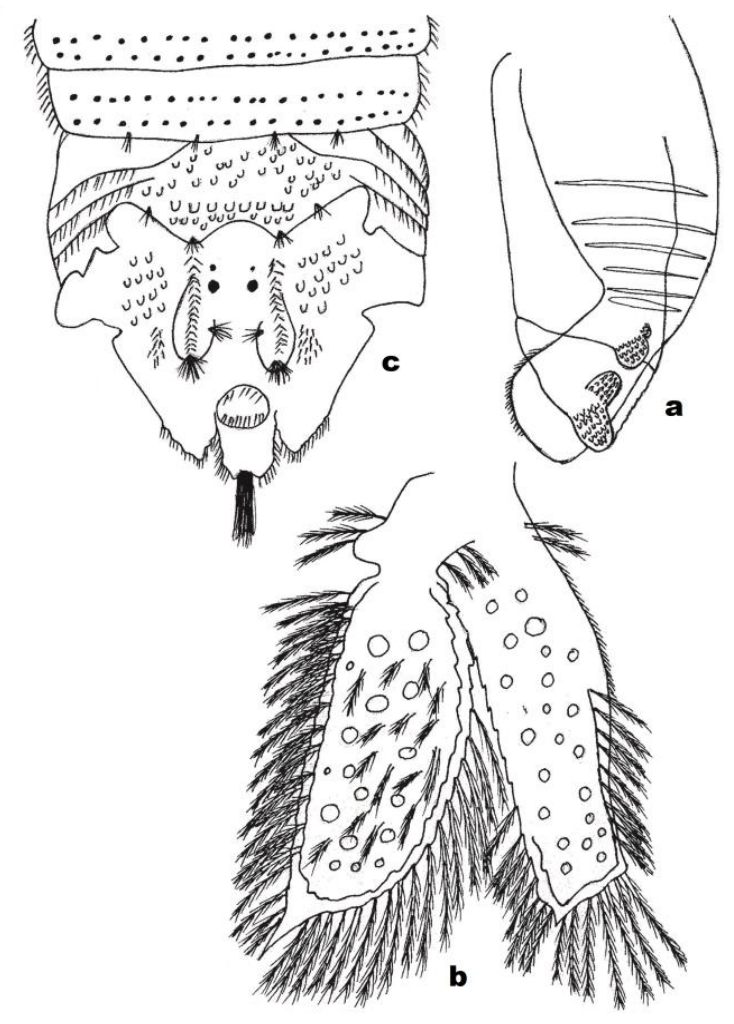

Figure 10. C. tribullis: pleopod 5 (a), Uropods (b), Pleotelson (c)

ment for the abundant and diverse organisms [19] and offer protection against physical stresses, such as air exposure, waves, desiccation, protection from predation and as well as serves as a food source to these associated fauna [26]. The present study also observed other associated macrofaunal communites associated with seaweeds. Comprising seven phyla namely Annelida, Arthropoda, Echinodermata, Mollusca, Sipuncula, Nemertea, and Pycnogonida have been reported. The arthropods were the major groups which includes amphipoda (families, Ischyroceridae and Ampithoidae) and Isopoda (Genera, Cerceis, Sphaeroma, Exosphaeroma, Excirolana, Cirolana), followed by Annelida (Syllis sp. Nereis sp and Serpulidae) and Molluscan families such as Epitoniidae, Buccinidae, Littorinidae, Cerithiidae, Columbellidae, Neritidae, Potamididae, and Mitridae. The epifauna found in this study was similar to earlier works reports [27, 28, 29, 30,19].

\section{Conclusion}

Andaman and Nicobar Islands have long and highly productive coastal region with great marine faunal diversity. Due to its remoteness and lack of research, research on marine isopods in Andaman and Nicobar Islands has received little attention for decades. Arthropod groups such as isopoda and amphipod have the powerful grasping appendages to hold firmly on the cylindrical filaments of sea weeds. The reports of the seaweed associated isopods from Andaman and Nicobar Islands are very scanty. In the present study two isopoda species Metacirolana sp. and Cymodoce tribullis were recorded for the first time from South Andaman, Andaman Islands. This study added another two species of isopods, genus Metacirolana and Cymodoce tribullis to isopoda check list of Andaman and Nicobar Islands.

\section{Acknowledgement}

The authors thank Pondicherry University for providing the necessary facilities to carry out this research. First author is also grateful to Dr. David Holdich for providing valuable identification keys for C. tribullis species identification and Dr. Niel L. Bruce, Museum of Tropical Queensland, Queensland Museum, Townsville, Australia for helping in genus Metacirolana identification.

\section{References}

1. Ricardo JC, Paiva, Jesser F, Souza-Filho (2014) A new species of Cirolana Leach, 1818 (Isopoda, Cymothoidea, Cirolanidae) from Brazilian coast. Nauplius 22 (2): 91-102. doi: 10.1590/S0104-64972014000200003.

2. Poore GCB, Bruce NL (2012) Global diversity of marine isopods (except Asellota and crustacean symbionts). PLoS ONE 7(9):1-15. doi: 10.1371/journal.pone.0043529.

3. Keable SJ (2006) Taxonomic Revision of Natatolana (Crustacea: Isopoda: Cirolanidae). Records of the Australian Museum 58 (2): 133-44.doi:10.3853/j.0067-1975.58.2006.1469.

4. Menzies RJ, George RY (1972) Isopod Crustacea of the PeruChile Trench. Anton Bruun Report 9. Scientific Results of the Southeast Pacific Expedition, Texas A \& M Press: College Station Texas 9:1-124.

5. Sidabalok C, Bruce NL (2015) Revision of the cirolanid isopod genus Odysseylana Malyutina, 1995 (Crustacea) with description of two new species from Singapore. Zootaxa 4021(2): 351367. doi:10.11646/zootaxa.4021.2.6.

6. Bruce NL (1996) Crustacea Isopoda: Some Cirolanidae from the Musorstom Cruises off New Caledonia. Résultats des Campagnes Musorstom,Volume 15. Mémoires du Muséum National d'Histoire Naturelle, Paris pp.168: 147-166.

7. Bruce NL, Schotte M (2013) Metacirolana Kussakin, 1979. World Marine, Freshwater and Terrestrial Isopod Crustaceans database. http://www.marinespecies.org/Isopoda/aphia.php?p= 
taxdetails\&id=118403. Accessed date: 31 July 2017).

8. Sidabalok CM, Bruce NL (2018) Two new species and a new record of Metacirolana Kussakin, 1979 (Crustacea: Isopoda: Cirolanidae) from Indonesia. Zootaxa 4370 (5): 519-534. doi: 10.11646/zootaxa.4370.5.4.

9. Schotte M (2012) Cymodoce. In: Schotte M, Boyko CB, Bruce NL, Poore GCB, Taiti S, Wilson GDF, eds. World Marine, Freshwater and Terrestrial Isopod Crustaceans database. http://www.marinespe-

cies.org/isooda/aphia.php?p=taxdetails\&id=118426. Accessed date: 10 July 2012.

10. Khalaji-Pirbalouty V, Bruce NL, Wägele JW (2013) The genus Cymodoce Leach, 1814 (Crustacea: Isopoda: Sphaeromatidae) in the Persian Gulf with description of a new species. Zootaxa 3686 (5): 501-533. doi: 10.11646/zootaxa.3686.5.1.

11. Harrison K, Holdich DM (1984) Hemibranchiate sphaeromatids (Crustacea: Isopoda) from Queensland, Australia, with a worldwide review of the genera discussed. Zoological Journal of the Linnean Society 8: 275-387.

12. Khalaji-Pirbalouty V, Bruce NL (2014) A review of the genus Heterodina Kensley \& Schotte, 2005 (Crustacea: Isopoda: Sphaeromatidae) with description of a new species from Iran. Zootaxa 3887 (3): 494-500. doi:10.11646/zootaxa.3887.4.7.

13. Khalaji-Pirbalouty V (2016) A new species of Cymodoce from Iran (Crustacea: Isopoda: Sphaeromatidae) with remarks on the status of Cymodoce manorii (Nooruddin, 1965) comb. nov. and Cymodoce spinula Yousuf \& Javed, 2001. Zootaxa 4084 (2): 267-276. doi:10.11646/zootaxa.4084.2.6.

14. Saravanakumar A, Rajkumar M, Thivakaran GA, Sesh Serebiah J (2008) Abundance and seasonal variations of phytoplankton in the creek waters of western mangrove of Kachchh-Gujarat. Journal of Environmental Biology 29(2): 271-274.

15. Castro P, Huber ME (2003) Marine Biology. The McGraw Hill Companies, USA.

16. Paerl HW, Justić D (2011) Primary producers: Phytoplankton ecology and tropic dynamics in coastal waters. In: Wolanski E, Mclusky DS, eds. Treatise on Estuarine and Coastal Science. Waltham, Academic Press. 23-42.

17. Van Dam RA, Harford AJ, Houston MA, Hogan AC, Negre AP (2008) Tropical marine toxicity testing in Australia: a review and recommendations. Australasian Journal of Ecotoxicology 14: 55-88

18. Mantri VA (2005) Changes in local intertidal seaweed habitats in the Andaman and Nicobar Islands after 26 December 2004 tsunami. Current Science 89 (7): 1071-1072.

19. Anandavelu I, Jayabarathi R, Padmavati G, Jayaraj KA (2013) Epifaunal assemblage on morphologically distinct intertidal seaweeds of Kodiyaghat (South Andaman), India. Proceedings of the International Academy of Ecology and Environmental Sciences 3 (3): 229-237.

20. Brusca RC, Wetzer R, France, SC (1995) Cirolanidae (Crustacea: Isopoda: Flabellifera) of the Tropical Eastern Pacific. Proceedings of the San Diego society of Natural History 30: 1-96.

21. Dev Roy MK (2013) Marine and Estuarine Isopod Fauna (Crustacea:Isopoda) of India. Journal of Environment and Sociobiology 10: 2.

22. Barnard KH (1936) Isopods collected by the R.I.M.S Investigator. Records of the Indian Museum 38:147-191.

23. Lowry JK, Dempsey K (2006) The giant deep-sea scavenger genus Bathynomus (Crustacea, Isopoda, Cirolanidae) in the IndoWest Pacific. In: Richer de Forges B, Justone JL, eds. Tropical Deep-sea benthos. Paris, V 24 Memoires du Museum national D Histoire Naturelle. 163-192.

24. Bruce NL, Wong HPS (2015) An overview of the marine Isopoda (Crustacea) of Singapore. Raffles Bulletin of Zoology 3: 152-168.

25. Sidabalok CM (2013) List of marine isopods recorded from Indonesian waters. Marine Research Indonesia 38(1):49-66.

26. Lemieux J, Cusson M (2014) Effects of Habitat-Forming Species Richness, Evenness, Identity, and Abundance on Benthic Intertidal Community Establishment and Productivity. PLoS ONE 9(10): e109261.doi: 10:1371/journal.pone.0109261.

27. Roberts DA, Poore AGB (2005) Habitat configuration affects colonization of epifauna in a marine algal bed. Biological Conservation 127: 18-26.

28. Schmidt AL, Scheibling RE (2006) A comparison of epifauna and epiphytes on native kelps (Laminaria sp.) and an invasive alga (Codium fragile ssp. tomentosoides) in Nova Scotia, Canada. Botanica Marina 49: 315-330.

29. Bracken MES, Dorantes CAG, Stachowicz JJ (2007) Wholecommunity mutualism: Associated invertebrates facilitate dominant habitat-forming seaweed. Ecology 88: 2211-2219.

30. Cacabelos E, Olabarria C, Incera M, Troncoso JS (2010) Effects of habitat structure and tidal height on epifaunal assemblages associated with macroalgae. Estuarine Coastal and Shelf Science 89: 43-52. 
This page is intentionally left blank. 